\title{
New England States
}

National Cancer Institute

\section{Source}

National Cancer Institute. New England States. NCI Thesaurus. Code C43439.

The area in the United States comprised of the following states: Maine, New Hampshire, Vermont, Massachusetts, Rhode Island, Connecticut, and New Jersey. 